\title{
Pengaruh Penggunaan Teknologi Informasi, Motivasi Kerja, dan Kepuasan Kerja Terhadap Kinerja Guru SMA Negeri 82 Jakarta Selama Masa Pandemi Covid-19
}

\author{
Mutiara Sari Pratiwi \\ Universitas Pembangunan Nasional Veteran Jakarta, Indonesia \\ Author E-mail: mutiara.sp@upnvj.ac.id
}

\begin{abstract}
A B S T R A K
Perubahan sistem pendidikan akibat pandemi covid-19 telah menghasilkan kebijakan baru dalam proses pembelajaran dengan bantuan teknologi canggih dan perangkat internet. Meskipun internet dan teknologi bukanlah hal baru dan asing bagi masyarakat Indonesia, namun tidak dapat dipungkiri bahwa kemampuan penggunaan alat-alat teknologi di Indonesia belum sepenuhnya terdistribusi, terutama bagi para lansia dan sekolah-sekolah di daerah tertentu. Oleh karena itu, pada kenyataannya di masa covid-19 ini masih ada proses pembelajaran dengan hanya memberikan tugas melalui aplikasi chat WhatsApp tanpa ada interaksi tatap muka melalui Gmeet atau Zoom. Hal yang sama dialami oleh guru di SMA Negeri 82 Jakarta dan mempengaruhi kualitas kinerja yang dihasilkan guru. Agar berbanding lurus antara kinerja guru dengan tujuan pendidikan yang ditetapkan pemerintah, maka guru sebagai sumber daya manusia utama dalam organisasi harus berkompeten dengan memenuhi berbagai kompetensi penilaian. Untuk meningkatkan kompetensi guru perlu memahami pemanfaatan teknologi, motivasi dan kepuasan kerja sebagai pendorong untuk melahirkan semangat kerja guru dalam melaksanakan pekerjaannya.
\end{abstract}

Kata Kunci: Penggunaan Teknologi Informasi, Motivasi Kerja, dan Kepuasan Kerja.

\section{A B S T R A C T}

Changes in the education system due to the covid-19 pandemic have resulted in new policies in the learning process with the help of advanced technology and internet devices. Although the internet and technology are not new and foreign to the people of Indonesia, it cannot be denied that the ability to use technological tools in Indonesia has not been fully distributed, especially for the elderly and schools in certain areas. Therefore, in reality, during this covid-19 period, there is still a learning process by only giving assignments through the WhatsApp chat application without any face-to-face interaction via Gmeet or Zoom. The same thing is experienced by teachers at SMA Negeri 82 Jakarta and affects the quality of performance produced by teachers. In order to be directly proportional between teacher performance and educational goals set by the government, the teacher as the main human resource in the organization must be competent by fulfilling various assessment competencies. To improve the competence of teachers, 
it is necessary to understand the use of technology, motivation and job satisfaction as a driver to give birth to the work spirit of teachers in carrying out their work.

Key word: Use of Technology, Work Motivation, and Job Satisfaction.

Copyright $(2021$ Authors. This is an open access article distributed under the Creative Commons Attribution License, which permits unrestricted use, distribution, and reproduction in any medium, provided the original work is properly cited.

\section{PENDAHULUAN}

Kemajuan zaman kian hari akan terus mengalami perkembangan, setiap individu dituntut untuk dapat bersaing bukan hanya dengan sesama warga negaranya tetapi juga dengan warga negara lain. Agar dapat bersaing dengan lingkup global maka diperlukan ilmu pengetahuan dan kemampuan yang tinggi yang diperoleh dari pendidikan baik itu formal maupun non-formal. Sebab pendidikan disuatu negara dianggap sangat penting karena dapat mempengaruhi kualitas hidup manusianya, termasuk di Indonesia. Seperti Sekolah Menengah Atas Negeri 82 Jakarta yang menjadi salah satu tempat pendidikan yang bertumpuan pada pemerintah. Label nilai akreditasi "A" menjadikan sekolah ini sebagai salah satu sekolah favorite para siswa yang baru lulus dari jenjang menengah pertama. Melihat begitu besarnya harapan siswa terhadap ilmu yang akan mereka peroleh dari sekolahan tersebut dan sebagai salah satu sekolah milik negara, maka para sumber daya manusia yang terlibat sebaiknya sadar akan besarnya pengaruh hasil kinerja guru yang dimiliki serta dampaknya terhadap perkembangan mutu pendidikan di Indonesia.

Kinerja guru saat ini diuji dengan adanya fenomena wabah covid-19 atau virus korona (corona virus) yang menyerang hampir di seluruh penjuru dunia sebab penularannya yang bersifat sangat cepat melalui kontak antar manusia, dan kini virus tersebut telah genap satu tahun memasuki Indonesia. Kehadiran wabah ini mengakibatkan semua sistem pada setiap bidang kehidupan termasuk pendidikan mengalami perubahan yang signifikan. Menteri Pendidikan dan Kebudayaan (Mendikbud), Nadiem Anwar Makarim, mengeluarkan Surat Edaran Nomor 4
Tahun 2020 tentang Pelaksanaan Pendidikan dalam peristiwa Covid-19 dan mewajibkan pada semua tempat pendidikan sekolah, kursus, dan kampus untuk melakukan kegiatan pembelajaran dari rumah masing-masing dengan maksud memastikan terpenuhinya hak pelajar atau mahasiswa dalam mendapatkan jasa pendidikan selama darurat pandemi virus Covid-19. Dengan ini masyarakat dianjurkan untuk work and study from home selama virus ini masih dalam masa penanganan. Kebijakan pemerintah tersebut memaksa para guru agar melaksanakan edukasinya secara daring Pembelajaran Jarak Jauh (PJJ) dengan bantuan internet dan alat teknologi pribadi seperti laptop, komputer, dan handphone.

Hasil survey Lembaga Pusat Teknologi Informasi dan Komunikasi Pendidikan dan Kebudayaan (Pustekkom) Kementerian Pendidikan dan Kebudayaan (Kemendikbud) yang dikutip dari Merdeka.com (2021) bahwa guru non-teknologi yakni guru-guru yang tidak mengajar materi teknologi informasi dan komunikasi di Indonesia pada tahun 2018 tercatat sebesar 60\% masih gagap terhadap teknologi atau memiliki kemampuan yang sangat minim dalam penggunaan teknologi informasi. Agar dapat berbanding lurus antara kinerja guru dengan tujuan pendidikan yang ditetapkan pemerintah, maka guru sebagai sumber daya manusia utama dalam organisasi harus berkompeten dengan memenuhi berbagai kompetensi penilaian tertentu. Untuk meningkatkan kompetensi guru maka diperlukannya motivasi sebagai dorongan guna melahirkan semangat kerja guru dalam melaksanakan pekerjaannya.

Setiap manusia membutuhkan adanya motivasi, 
sementara dalam kenyataannya tidak mudah untuk dapat memotivasi seseorang. Hal ini dikarenakan berbagai faktor dan perbedaan karakteristik tiap individu itu sendiri dalam menanggapi sesuatu yang terjadi dalam hidupnya berkaitan dengan kemampuan. Dengan ini kemampuan yang diberikan dapat berupa keterampilan, tenaga serta waktu yang dimiliki guna tercapainya sasaran organisasi yang telah ditetapkan. Pegawai yang merasa bahwa pekerjaannya membosankan, mulai merasa kejenuhan, stuck, bahkan stress dan tidak memperoleh motivasi yang mampu mendukungnya untuk bangkit, baik dari pihak internal organisasi, keluarga, ataupun teman, maka secara otomatis akan menurunkan kinerja pegawai tersebut. Oleh sebab itu, masalah ini perlu dihindari dan dicari solusinya oleh manajemen sumber daya manusia atau pimpinan organisasi sebagai tugasnya dalam mengelola para pegawai hingga menghasilkan pegawai yang memelihara semangat dan tanggung jawab kerja yang tinggi.

Selain dengan kemampuan penggunaan teknologi dan pemberian motivasi, kepuasan kerja juga merupakan salah satu faktor yang mempengaruhi kinerja guru. Kepuasan kerja ditandai dengan suatu nilai positif yang lahir dalam diri seseorang khususnya guru dalam hal ini kepada pekerjaannya sebagai pendidik, kemudian kepuasan ini memotivasi dirinya untuk meningkatkan kinerja. Guru akan merasa puas apabila segala kebutuhan hidupnya telah terpenuhi oleh organisasi. Kebutuhan bukan hanya berupa materi tetapi juga kebutuhan psikis seperti tercapainya cita-cita dan harapan sebagai guru yang menguasai materi mata pelajaran tertentu mampu mengajar mata pelajaran tersebut dan bukan dibebankan dengan mengajar mata pelajaran lain yang hanya diketahui dasarnya saja. Selain itu keberhasilan dalam melahirkan prestasi peserta didik yang unggul, keselarasan budaya organisasi dengan nilai pribadi, promosi jabatan, hubungan kerja yang harmonis, pengalaman yang diperoleh selama kerja dan adanya kepemimpinan yang memotivasi. Bila kebutuhan ini tidak diterpenuhi dan berlarut lama maka akan menghasilkan kekecewaan, perasaan sedih hingga frustasi sehingga menurunkan produktivitas guru kemudian akan berujung kepada ketidakpuasan dan penurunan kinerja guru.

Mengacu pada latar belakang yang telah disampaikan, maka perumusan masalah dalam penelitan ini dapat ditentukan sebagai berikut: 1. Apakah terdapat pengaruh penggunaan teknologi informasi terhadap kinerja guru SMA Negeri 82 Jakarta?

2. Apakah terdapat pengaruh motivasi kerja terhadap kinerja guru SMA Negeri 82 Jakarta?

3. Apakah terdapat pengaruh kepuasan kerja terhadap kinerja guru SMA Negeri 82 Jakarta?

Dengan demikian, tujuan penelitian ini yakni:

1. Untuk mengetahui dan membuktikan pengaruh penggunaan teknologi informasi terhadap kinerja guru SMA Negeri 82 Jakarta.

2. Untuk mengetahui dan membuktikan motivasi kerja terhadap kinerja guru SMA Negeri 82 Jakarta.

3. Untuk mengetahui dan membuktikan pengaruh kepuasan kerja terhadap kinerja guru SMA Negeri 82 Jakarta.

\section{METODE}

Jenis penelitian ini adalah penelitian kuantitatif. Khususnya penelitian ini, yang dijadikan populasi ialah guru-guru PNS SMA Negeri 82 Jakarta yang berjumlah 34 orang dan pada penelitian ini peneliti akan mengambil sampel yang tersedia secara menyeluruh yang dikenal sebagai sampel jenuh. Selanjutnya dalam pengumpulan data dan pengukuran variabel yaitu dengan menggunakan kuisioner serta melalui pengukuran secara skala Likert. Teknik analisis data yang digunakan dalam penelitian ini dengan menggunakan analisis deskriptif, analisis inferensial, uji validitas, uji reabilitas, uji koefisien determinan (R2), dan uji hipotesis dengan menggunakan t-statistik.

\section{Definisi Operasional}

Pada penelitian ini digunakannya definisi 
operasional pada tiap variabel yang digunakan, sebagai berikut:

\section{Kinerja Guru}

Kinerja guru yakni hasil akhir kerja yang diperoleh guru atas tugasnya hingga mencapai tujuan dari organisasi. Kinerja guru adalah skor penilaian yang diperoleh dari jawaban responden melalui instrument indikator persiapan pembelajaran, perilaku manajemen kelas, dan peningkatan pembelajaran siswa.

2. Penggunaan Teknologi Informasi

Teknologi informasi yakni suatu alat hardware dan software yang digunakan sebagai pemrosesan data hingga menghasilkan suatu informasi yang berguna serta manfaatnya sebagai alat bantu manusia dalam memenuhi kebutuhannya secara efektif. Penggunaan teknologi informasi adalah skor penilaian yang diperoleh dari jawaban responden melalui instrument dengan indikator Makes job easier; Usefull; Increase productivity; Enchance effectiveness; dan Improve job performance.

3. Motivasi Kerja

Motivasi kerja yakni sesuatu tindakan yang memberikan efek kepada pihak lain untuk melakukan suatu tindakan aktif yang sesuai dengan lingkungan dengan maksud mencapai tujuan yang diinginkan. Motivasi kerja adalah point penilaian yang dikumpulkan dari respon responden melalui instrumen dengan indikator tantangan dan pencapaian, penghargaan, sikap perhatian, tunjangan tambahan, keamanan, promosi, dan lingkungan kerja.

4. Kepuasan Kerja

Kepuasan kerja adalah kondisi emosional yang menyenangkan yang dihasilkan dari penilaian pekerjaan atau pengalaman kerja seseorang. Kepuasan kerja yakni skor penilaian yang didapat dari jawaban responden melalui instrument dengan indikator kesempatan untuk maju, kemampuan kerja, pimpinan, organisasi dan menajemen, gaji, rekan kerja, dan kondisi kerja.

\section{HASIL DAN PEMBAHASAN}

\section{Analisis Deskriptif}

Sehubung penelitian ini, tindakan yang dilakukan yaitu penyebaran kuesioner melalui google form kepada sebanyak 34 responden yakni guru PNS SMA Negeri 82 Jakarta. Berikut merupakan deskripsi data dari responden berdasarkan jenis kelamin:

Tabel 1. Data Jenis Kelamin Responden

\begin{tabular}{cc}
\hline J. Kelamin & Persentase \\
\hline $\mathrm{L}$ & $47,1 \%$ \\
\hline $\mathrm{P}$ & $52,9 \%$ \\
\hline Jumlah & $\mathbf{1 0 0 \%}$ \\
\hline
\end{tabular}

Sumber: Data diolah (2021)

Sesuai Tabel 1 pada data jenis kelamin, menunjukkan guru PNS yang berjenis kelamin L (laki-laki) mewakili $47,1 \%$ sementara jenis kelamin P (perempuan) mewakili 52,9\%. Sehingga dapat diketahui bahwa guru PNS SMA Negeri 82 Jakarta didominasi oleh berjenis kelamin perempuan yakni sebesar $52,9 \%$ dari jumlah populasi.

Tabel 2. Data Usia Responden

\begin{tabular}{cc}
\hline Usia Guru & Persentase \\
\hline $24-30$ & $14,7 \%$ \\
\hline $31-36$ & $11,8 \%$ \\
\hline $37-42$ & $5,9 \%$ \\
\hline $43-48$ & $11,8 \%$ \\
\hline $49-54$ & $26,4 \%$ \\
\hline $55-60$ & $29,4 \%$ \\
\hline Jumlah & $\mathbf{1 0 0} \%$ \\
\hline
\end{tabular}

Sumber: Data diolah (2021)

Interval data usia diatas diperoleh dari perhitungan: $P=\frac{\text { Range }}{\text { Banyak Kelas }}=\frac{36}{6}=6$

Berdasarkan pada Tabel 2 diatas, dapat disimpulkan bahwa data usia responden pada penelitian ini dimana usia responden antara 24 hingga 30 tahun sebanyak $14,7 \%$, bagi responden dengan usia 31 hingga 36 tahun sebesar $11,8 \%$, kemudian usia 37 tahun hingga 42 tahun sebesar 5,9\%, 43 hingga 48 tahun sebesar 11,8\%, 49 hingga 54 tahun sebesar $26,4 \%$ dan yang terakhir berada pada usia 55 
hingga 60 tahun sebesar 29,4\%. Sehingga dapat diketahui mayoritas guru PNS SMA Negeri 82 Jakarta didominasi pada rentang usia 55 hingga 60 tahun atau $29,4 \%$ dari jumlah populasi.

Kemudian data dari masa kerja responden, yang dikelompokan untuk memudahkan proses tabulasi data, pada penelitian ini pengelompokkan masa kerja terdiri dari 1 hingga 10 tahun, 11 hingga 20 tahun, 21 hingga 30 tahun, dan $>30$ tahun.

Tabel 3. Data Masa Kerja Responden

\begin{tabular}{cc}
\hline Masa Kerja & Persentase \\
\hline 1-10Tahun & $23,5 \%$ \\
\hline 11-20Tahun & $20,5 \%$ \\
\hline 21-30Tahun & $29,5 \%$ \\
\hline >30Tahun & $26,5 \%$ \\
\hline Jumlah & $\mathbf{1 0 0} \%$ \\
\hline
\end{tabular}

Sumber: Data diolah (2021)

Tabel 3 diatas menunjukkan data masa kerja responden, diketahui masa kerja kurang dari 10 tahun mewakili 23,5\%, bagi masa kerja 11 hingga 20 tahun sebesar 20,5\%, kemudian yang memiliki masa kerja 21 hingga 30 tahun sebesar $29,5 \%$ serta bagi responden yang masa kerja lebih dari 31 tahun yaitu mewakili sebesar $26,5 \%$. Sehingga dipahami guru PNS SMA Negeri 82 Jakarta memiliki masa kerja paling banyak yakni pada 21-30 tahun atau 29,5\% dari jumlah populasi. Hal ini dikarenakan guru PNS yang tersedia di SMA Negeri 82 merupakan guru-guru senior yang telah memasuki usia $>51$ tahun dan telah memiliki pengalaman yang memadai.

Tabel 4. Data Jabatan Kerja Responden

\begin{tabular}{cc}
\hline Jabatan & Persentase \\
\hline Kepala Sekolah & $2,95 \%$ \\
\hline Wakil Kepala Sekolah & $11,76 \%$ \\
\hline Guru & $85,29 \%$ \\
\hline Total & $\mathbf{1 0 0 \%}$ \\
\hline
\end{tabular}

Sumber: Data diolah (2021)

Pada Tabel 4 ialah data jabatan kerja, dapat diketahui bahwa responden yang memiliki jabatan kerja sebagai kepala sekolah sebesar $2,95 \%$, untuk yang memiliki jabatan sebagai wakil kepala sekolah yaitu sebesar $11,76 \%$ dimana wakil kepala sekolah ini terdiri dari wakil kepala sekolah bidang kurikulum dan bidang kesiswaan dengan masing-masing dua orang, kemudian yang memiliki jabatan sebagai guru biasa sebesar 85,29\%. Sehingga dapat diketahui bahwa guru PNS SMA Negeri 82 Jakarta memiliki jabatan kerja paling banyak yakni sebagai guru pengajar biasa atau $85,29 \%$ dari jumlah populasi.

Uji Validitas dan Reliabilitas

Dalam penelitian ini untuk menguji validitas dan reliabilitas data menggunakan dua model yakni outer model dan inner model.

\section{a. Model Pengukuran (Outer Model)}

Pada tahap awal analisis inferensial dalam penelitian dimulai dengan membuktikan apakah model yang digunakan telah merealisasikam convergent validity atau belum, dan memastikan loading factor indikator pada tiap construct Teknologi Informasi, Motivasi Kerja, Kepuasan Kerja, dan Kinerja Guru sudah memenuhi convergent validity dengan outer model. Berikut hasil outer model pada smart PLS 3.0:

Pada penelitian yang dilakukan oleh peneliti, dalam mengukur convergent validity dipahami melalui indikator reflektif atau indikator yang dapat dikatakan valid apabila diperoleh nilai korelasi lebih dari 0,7. Akan tetapi berdasarkan teori Ghazali bahwa nilai skala 0,5 - 0,6 telah memenuhi kriteria dan masih dapat dikatakan valid (Ghozali, 2014, p. 40).

\section{b. Uji Validitas Konvergen}

Dalam penelitian ini tidak ditemukan 46 indikator dengan pernyataan yang memiliki nilai dibawah 0,5 dan berdasarkan hasil tersebut maka tidak akan dilakukan re-estimasi kembali atas model penelitian tersebut. Demikian dapat diartikan bahwa semua instrumen dari setiap indikator mengenai variabel Penggunaan Teknologi Informasi, Motivasi Kerja, Kepuasan Kerja dan Kinerja Guru telah lulus persyaratan dan telah diakui valid. Dikatakan valid sebab semua angka korelasi nilai loading factor diatas 0,5. Berdasarkan hal ini maka outer model telah 


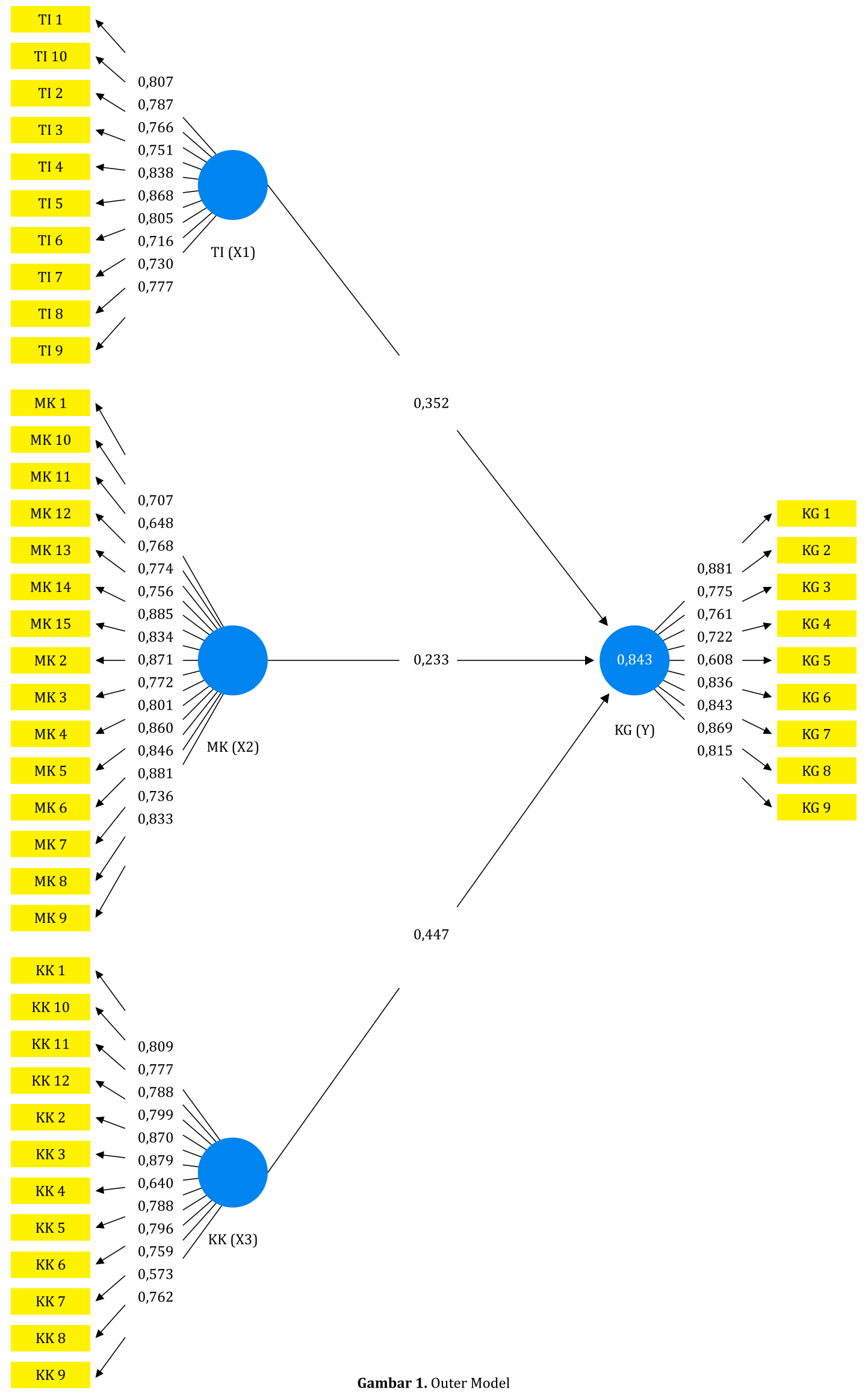

Sumber: Hasil Output PLS 3.0 
dinyatakan baik dan dapat dilanjutkan ketahap selanjutnya.

\section{c. Uji Validitas Diskriminan}

Pada Tabel 5. diatas bahwa discriminant validity melalui Fornell Larcker Criterion pada tiap variabel construct nya, yang mencakup Kinerja Guru (Y) memiliki nilai sebesar 0.794, selanjutnya Penggunaan Teknologi Informasi (X1) senilai 0.786, kemudian Motivasi Kerja (X2) yaitu 0.801, dan Kepuasan Kerja (X3) diperoleh 0.773. Sehingga disimpulkan bahwa uji discriminant validity pada variabel Penggunaan Teknologi Informasi, Motivasi Kerja, Kepuasan Kerja dan Kinerja Guru telah valid dan termasuk sudah memenuhi uji validitas diskriminan.

Kemudian berdasarkan akar kuadrat dari Average Variance Extracted (AVE) yang terdiri dari Kinerja Guru (Y) yang memiliki nilai AVE sebesar 0.631, Penggunaan Teknologi Informasi (X 1) 0.617, Motivasi Kerja (X 2) 0.641, dan Kepuasan Kerja (X 3) 0.597. Hasil dengan metode AVE untuk variabel Penggunaan Teknologi Informasi, Motivasi Kerja, Kepuasan Kerja dan Kinerja Guru yakni dapat dikatakan baik dan telah memenuhi uji validitas diskriminan, sesuai yang dijelaskan oleh Ghozali diatas.

\section{Uji Realibitas}

\begin{tabular}{lcc}
\multicolumn{3}{c}{ Tabel 6. Composite Reliability (CR) } \\
\hline & $\begin{array}{c}\text { Composite } \\
\text { Reliability } \\
\text { (CR) }\end{array}$ & $\begin{array}{c}\text { Cronbach's } \\
\text { Alpha }\end{array}$ \\
\hline Penggunaan Teknologi Informasi (X1) & 0.941 & 0.931 \\
\hline Motivasi Kerja (X2) & 0.964 & 0.960 \\
\hline Kepuasan Kerja (X3) & 0.946 & 0.937 \\
\hline Kinerja Guru (Y) & 0.938 & 0.926 \\
\hline
\end{tabular}

Berdasarkan Tabel 6, terlihat bahwa hasil composite reliability bagi seluruh construct yitu $>0.7$ maknanya semua construct pada model yang sudah diestimasi lulus persyaratan (Ghozali, 2014, hlm. 41) karena composite reliability terendah sebesar 0,938 yakni construct kinerja guru, dan nilai composite reliability tertinggi sebesar 0,964, yakni construct motivasi kerja. Variabel Penggunaan Teknologi Informasi 0,941 dan Kepuasan Kerja 0,946. Dengan hal tersebut maka seluruh variabel yang digunakan reliabel pada setiap construct Penggunaan Teknologi Informasi, Motivasi Kerja, Kepuasan Kerja dan Kinerja Guru.

Berdasarkan penjelasan yang dinyatakan oleh Ghozali (2014, hlm. 41) maka nilai yang di pada Cronbach's Alpha yaitu $>0,7$ demikian pula pada tabel di atas telah menunjukkan bahwa nilai Cronbach's Alpha untuk semua construct pada penelitian ini sudah berada di atas nilai 0,7. Nilai Cronbach's Alpha yang terendah ialah sebesar 0.926 pada construct Kinerja Guru dan nilai tertinggi sebesar 0.960 pada construct Motivasi Kerja. Berdasarkan hal ini maka telah menunjukkan bahwa semua variabel pada penelitian ini sudah reliabel dan sangat reliabel terhadap masing-masing construct nya.

Berdasarkan penjelasan Ghozali (2014, p. 41), nilai cronbach's alpha direkomendasi yaitu $>$ 0.7, demikian pula Tabel 6 menunjukkan nilai cronbach's alpha semua construct dalam penelitian ini berada di atas nilai 0,7. Nilai alpha terendah yaitu 0,926 untuk construct kinerja guru dan tertinggi yaitu 0,960 untuk construct motivasi kerja. Berdasarkan hal ini maka telah membuktikan, tiap variabel yang digunakan

Sumber: Hasil Output SmartPLS 3.0

Tabel 5. Fornell-Larcker Criterion

\begin{tabular}{lccccc}
\hline & $\begin{array}{c}\text { Penggunaan } \\
\text { Teknologi } \\
\text { Informasi (X1) }\end{array}$ & $\begin{array}{c}\text { Motivasi } \\
\text { Kerja } \\
\text { (X2) }\end{array}$ & $\begin{array}{c}\text { Kepuasan } \\
\text { Kerja } \\
\text { (X3) }\end{array}$ & $\begin{array}{c}\text { Kinerja } \\
\text { Guru } \\
\text { (Y) }\end{array}$ & $\begin{array}{c}\text { Average } \\
\text { Variance } \\
\text { Extracted (AVE) }\end{array}$ \\
\hline Penggunaan Teknologi Informasi (X1) & $\mathbf{0 . 7 8 6}$ & & & 0.617 \\
\hline Motivasi Kerja (X2) & 0.684 & $\mathbf{0 . 8 0 1}$ & & 0.641 \\
\hline Kepuasan Kerja (X3) & 0.694 & 0.655 & $\mathbf{0 . 7 7 3}$ & & 0.597 \\
\hline Kinerja Guru (Y) & 0.821 & 0.766 & 0.684 & $\mathbf{0 . 7 9 4}$ & 0.631 \\
\hline
\end{tabular}

Sumber: Hasil Output PLS 3.0 
sangat reliabel untuk construct apapun.

\section{Uji Koefisien Determinasi $\left(\mathbf{R}^{2}\right)$}

\begin{tabular}{lcc}
\multicolumn{3}{c}{ Tabel 7. R Square } \\
\hline & R Square & R Square Adjusted \\
\hline Kinerja Guru $(\mathrm{Y})$ & 0.843 & 0.828 \\
\hline
\end{tabular}

Sumber: Hasil Output SmartPLS 3.0

Dari data pada Tabel 7, diketahui bahwa pengaruh Penggunaan Teknologi Informasi, Motivasi Kerja dan Kepuasan Kerja masing-masing memberikan kontribusi sebesar 0,843 atau $84,3 \%$ terhadap kinerja guru, sedangkan $15,7 \%$ variabel lain yang tidak disertakan. Artinya, model penelitian ini bisa disebut baik, sehingga bisa dilanjutkan.

\section{Uji Hipotesis}

\begin{tabular}{lccc} 
& Tabel 8. Uji t-Statistik & \\
\hline & $\begin{array}{c}\text { Original } \\
\text { Sample (0) }\end{array}$ & $\begin{array}{c}\text { T Statistics } \\
(\mid \mathbf{O} / \text { STDEV|) }\end{array}$ & P Values \\
\hline $\begin{array}{l}\text { Penggunaan } \\
\text { Teknologi Informasi } \\
\text { (X1) -> Kinerja }\end{array}$ & 0.352 & 2.236 & 0.026 \\
Guru (Y) & & & \\
\hline $\begin{array}{l}\text { Motivasi Kerja } \\
\text { (X2) -> Kinerja }\end{array}$ & 0.233 & 2.023 & 0.044 \\
Guru (Y) & & & \\
\hline $\begin{array}{l}\text { Kepuasan Kerja } \\
\text { (X3) -> Kinerja }\end{array}$ & 0.447 & 2.810 & 0.005 \\
Guru (Y) & & & \\
\hline
\end{tabular}

Sumber: Hasil Output SmartPLS 3.0

Didapati t-tabel dalam penelitian ini ialah 1.692 dari hitungan denga rumus df (Degrees of Freedom $/$ nilai kebebasan $=\mathrm{n}($ jumlah sampel $)-1$ sehingga dalam penelitian ini $\mathrm{df}=34-1=33$, serta memakai derajat kebenaran sebesar $95 \%$ atau 0,05 .

Dari data di atas diperoleh gambar inner model sebagai berikut:

Sesuai pada tabel tersebut maka diperoleh variabel Penggunaan Teknologi Informasi terhadap Kinerja Guru memiliki pengaruh positif, yang ditandai nilai original sample sebesar 0.352 atau $35,2 \%$. Jika dilihat berdasarkan uji t-statistik bahwa dapat diketahui thitung 2.236 $>$ tabel 1.692 dengan demikian diartikan variabel Penggunaan Teknologi Informasi memiliki pengaruh terhadap Kinerja Guru. Selain itu nilai signifikansi ( $P$ Values) yang diperoleh sebesar $0,026<0,05$ menunjukkan bahwa variabel Penggunaan Teknologi Informasi berpengaruh dan signifikan terhadap Kinerja Guru.

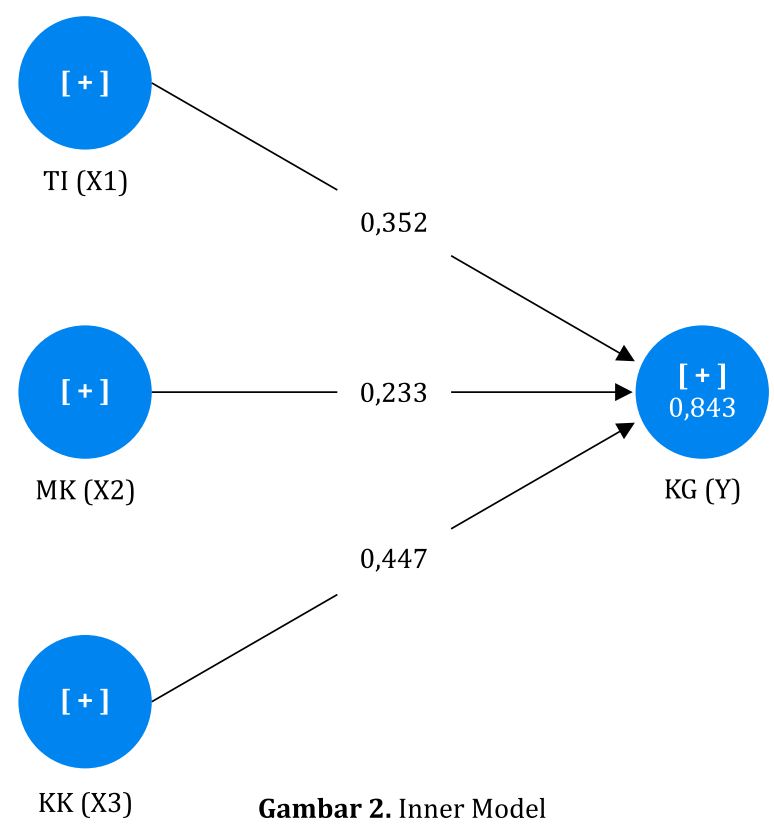

Sumber: Hasil Output SmartPLS 3.0

Selanjutnya, sehubungan pada Tabel 8 diatas dapat disimpulkan bahwa hasil pengujian pada variabel Motivasi Kerja terhadap Kinerja Guru memiliki pengaruh positif. Tafsiran ini ditandai dengan nilai original sample sebesar 0.233 atau 23,3\%. Jika dilihat dari hasil pengolahan uji tstatistik dapat diketahui bahwa thitung 2.023> tabel 1.692, oleh demikian dapat diartikan bahwa variabel Motivasi Kerja memiliki pengaruh terhadap Kinerja Guru. Kemudian nilai signifikansi ( $P$ Values) diperoleh sebesar 0,044 $<0,05$ yang menunjukkan bahwa variabel Motivasi Kerja berpengaruh dan signifikan terhadap Kinerja Guru.

Melihat dari tabel diatas dapat disimpulkan bahwa hasil dari pengujian pada variabel kepuasan kerja terhadap kinerja guru memiliki pengaruh yang positif. Penafsiran ini ditandai dengan nilai original sample sebesar 0.447 atau $44,7 \%$. Jika dilihat dari hasil pengolahan uji tstatistik dapat diketahui bahwa thitung $2.810>$ tabel 1.692, sehingga dapat diartikan bahwa variabel 
Kepuasan Kerja memiliki pengaruh terhadap Kinerja Guru. Kemudian nilai signifikansi $(P$ Values) diperoleh sebesar 0,005 $<0,05$ yang memberi bukti bahwa variabel Kepuasan Kerja berpengaruh dan signifikan terhadap Kinerja Guru. Berdasarkan hasil yang diperoleh dari penelitian yang telah peneliti lakukan mengenai Pengaruh Penggunaan Teknologi Informasi, Motivasi Kerja, dan Kepuasan Kerja terdahap Kinerja Guru SMA Negeri 82 dengan memanfaatkan metode perhitungan Partial Least Square (PLS) serta menggunakan software SmartPLS 3.0, maka didapati hasil sebagai berikut, yaitu:

1. Pengaruh Penggunaan Teknologi Informasi terhadap Kinerja Guru SMA Negeri 82 Jakarta Berlandaskan dari hasil penelitian bahwa hasil pengujian hipotesis 1 (H1) yang menunjukan variabel Penggunaan Teknologi Informasi terhadap Kinerja Guru telah memiliki pengaruh yang positif, hal ini berdasarkan output dalam indikator increase productivity. Artinya mayoritas responden setuju bahwa selama masa pendemi mereka tetap usaha meningkatkan produktivitas kerjanya meskipun hanya bekerja dari rumah. Dimana para guru selama work from home ini diakui menjadi lebih sering berproduktif melalui teknologi informasi khususnya dalam rangka mengikuti web-seminar pendidikan/ workshop yang diadakan oleh antar guru dan hampir melakukan pertemuan (meeting) melalui teknologi serta melakukan segala aktivitas pekerjaan dengan bantuan teknologi dan juga internet. Dengan kata lain, mayoritas guru PNS di sekolah tersebut melaksanakan kegiatan aktif dengan bantuan teknologi informasi pribadinya untuk mempertahankan ataupun meningkatkan kinerja.

Meski demikian berdasarkan hasil pada indikator enchance effectiveness atau dalam hal memberikan efektivitas kerja yang tinggi pada pemanfaatan teknolog masih diperoleh sebagian kecil guru yang mengalami hambatan dalam memahami karakteristik peserta didiknya, hal ini dikarenakan pembelajaran jarak jauh yang mana tidak ada kontak langsung antara guru dengan murid secara intens seperti pada masa sebelum pandemi dimana murid dan guru bisa komunikasi secara langsung. Seperti yang kita ketahui, penilaian siswa terdiri dari beberapa poin-poin salah satunya merupakan penilaian atas sikap. Selama pembelajaran melalui daring ini dianggap kurang efektif untuk dapat menilai sikap siswa secara mendetail. Terlebih bagi peserta didik ajaran baru tahun 2020/2021 dimana belum ada pertemuan secara fisik baik dengan lingkungan sekolah dan warga sekolah, yang mengakibatkan guru kesulitan dalam memahami dan menilai poin sikap secara obyektif pada peserta didik.

Maka, dapat disimpulkan bahwa para guru PNS SMA Negeri 82 Jakarta mayoritasnya setuju bahwa teknologi informasi membantu meningkatkan produktivitas kerjanya meskipun pada masa pandemi yang mengharuskan setiap orang bekerja dari rumahnya masing-masing. Namun, masih terdapat sebagian kecil guru merasa bahwa selama work from home dengan menggunakan teknologi tidak dapat efektif dalam memahami dan menilai karakteristik siswa pada saat kegiatan belajar berlangsung. Dengan output yang diperoleh dari indikator yang digunakan pada penelitian ini, variabel penggunaan teknologi informasi secara praktis dapat dianggap signifikan. Selain itu diperoleh pula hasil dari nilai original sample sebesar 0.352 atau $35,2 \%$. Dari hasil pengolahan uji statistik uji-t yaitu nilai thitung $2.236>$ tabel 1.692 dan nilai $P$ Values $0.026<0.05$. Sehingga mampu diambil keputusan Ho ditolak dan Ha diterima. Dan dapat diartikan variabel Penggunaan Teknologi Informasi signifikan mempenagruhi Kinerja Guru.

Dapat dikatakan sejalan dengan penelitian Zakaria \& Leiwakabessy (2020), Nuskiya (2018), dan Yunus \& Bosowa (2019) yaitu Penggunaan Teknologi Informasi berpengaruh signifikan dan kuat pada Kinerja Guru. Dengan kata lain, penggunaan teknologi informasi mampu mempermudah kerja para guru yang hingga mereka dapat melakukan pekerjaannya secara lebih efektif dan efisien. Semakin efektif dan 
efisiennya kinerja guru, akan semakin tinggi jua kinerjanya dihasilkan. Berbeda dengan kajian Nugroho et al., (2019) dimana tinggi rendahnya penggunaan teknologi tidak dapat menghasilkan peningkatan kinerja pada karyawan.

2. Pengaruh Motivasi Kerja terhadap Kinerja Guru SMA Negeri 82 Jakarta

Berdasarkan dari hasil penelitian bahwa hasil pengujian hipotesis 2 (H2) yang menunjukan variabel Motivasi Kerja terhadap Kinerja Guru telah memiliki pengaruh yang positif, hal ini berasaskan hasil yang diperoleh dari dimensi ekstrinsik indikator lingkungan kerja artinya guru PNS di SMA Negeri 82 Jakarta setuju bahwa segala fasilitas, sarana dan prasarana yang tersedia oleh sekolah cukup memadai kebutuhan proses belajar mengajar. Sehingga dapat dikatakan tidak ada kendala kurangnya ketersediaan fasilitas di sekolah yang mengakibatkan guru tidak dapat menggunakan suatu teknologi sebagai media yang digunakan pada kegiatan belajar mengajar. Ada berbagai teknologi yang disediakan sekolah seperti proyektor/infocus, laptop, lab komputer, alatalat laboratorium, wifi, alat fotokopi, dan printer yang bisa digunakan dalam kegiatan belajar mengajar. Meski pada kondisi masa pandemi, beberapa guru tetap ada yang datang dan melaksanakan kegiatan belajar mengajar daring dari sekolah sehingga beberapa fasilitas tersebut masih terpakai dengan aktif.

Meski demikian tetap ada kendala yang dialami mengenai motivasi guru yaitu pada dimensi ekstrinsik indikator keamanan yang mana masih terdapat guru PNS SMA Negeri 82 Jakarta yang merasa bahwa pihak sekolah masih kurang aman dalam menyimpan berkas, data, atau file penting lainnya. Hal ini baik disebabkan oleh human error ataupun karena kegagalan fungsi teknologi (rusak). Meskipun teknologi yang dimiliki sekolah cukup canggih, namun kurangnya perhatian pihak sekolah terhdap fungsi dan kondisi teknologi mengakibatkan alat-alat teknologi tersebut terkesan tidak terurus, ketidakpedulian ini yang menyebabkan masalah kerusakan teknologi yang sering terjadi di suatu organisasi atau sekolah.

Maka, dapat disimpulkan bahwa para guru PNS SMA Negeri 82 Jakarta cukup memiliki fasilitas yang memumpuni dalam menjalankan tugasnya di sekolah sehingga dapat digunakan sebagai media pembelajaran. Selama masa pandemi minimal telah terpastikan bahwa masing-masing guru memiliki alat teknologi seperti laptop atau komputer pribadi di rumahnya serta sekolah menjamin setiap guru memperoleh bantuan kuota internet secara rutin agar aktivitas belajar mengajar dapat berjalan. Berdasarkan hasil, diperoleh dari indikator yang digunakan pada penelitian ini, variabel motivasi kerja secara praktis dapat dianggap signifikan.

Selain itu diperoleh pula hasil dari nilai original sample dengan nilai sebesar 0.233 atau 23,3\%. Dari perolehan uji-t yang mana nilai pada thitung $2.023>$ tabel 1.692 serta nilai signifikansi ( $P$ Values) senilai $0,044<0,05$. Demikian diambil keputusan bahwa Ho ditolak dan Ha diterima, dan dapat diartikan variabel Motivasi Kerja secara signifikan mempengaruhi Kinerja Guru. Hasil penelitian ini senada dengan Kartini \& Kristiawan (2019), Andriani et al., (2018) dan yaitu Motivasi Kerja mempengaruhi terhadap Kinerja Guru. Dimana ketika guru merasa termotivasi baik dari internal maupun eksternal yang tinggi, maka akan meningkatkan pula kinerjanya. Namun Adha et al., (2019) bertentangan dengan hasil penelitian ini, yakni Motivasi Kerja tidak ditemukan pengaruhnya terhadap Kinerja Karyawan.

3. Pengaruh Kepuasan Kerja terhadap Kinerja Guru SMA Negeri 82 Jakarta

Berdasarkan dari hasil penelitian bahwa hasil pengujian hipotesis 3 (H3) yang menunjukan variabel Kepuasan Kerja terhadap Kinerja Guru telah memiliki pengaruh yang positif, hal ini berdasarkan output yang diperoleh dari indikator kesempatan untuk maju yang artinya guru PNS di SMA Negeri 82 Jakarta merasa bahwa bekerja dari rumah selama masa pandemi memberikan mereka peluang dalam memperoleh kemampuan baru. Contohnya ialah 
penggunaan teknologi, yakni yang sebelumnya mereka jarang menggunakan teknologi sebagai media pembelajaran di dalam ruang kelas, kini mereka harus belajar terbiasa menggunakan teknologi sebagai media pembelajaran sehari-hari.

Di era globalisasi, kemampuan sumber daya manusia dalam menguasai perkembangan IPTEK sangat penting. Sebab hampir semua aktivitas manusia memerluan bantuan alat teknologi, sehingga apabila sumber daya manusia yang terkait kurang kompeten dalam mengoperasionalkan teknologi dengan baik, maka akan mudah bagi pesaing lainnya untuk dapat mengungguli. Namun pada pernyataan indikator penggajian masih diperoleh sebagian guru yang masih merasa adanya keterlambatan atau penguluran waktu penerimaan gaji khususnya selama masa pandemi. Permasalahan ini mungkin terjadi seperti dipergantian tahun karena ada proses penginputan data oleh pemerintah, pergantian sistem penggajian, atau kendala internal lainnya.

Maka, dapat disimpulkan bahwa para guru PNS SMA Negeri 82 Jakarta merasa senang karena dapat memperoleh ilmu yang mampu mengasah skill nya melalui pembelajarn daring ini. Meskipun sebagian lainnya merasa kondisi ekonominya terhambat dengan adanya pandemi covid-19 yang mengharuskan mereka untuk menerima dan bersabar dalam memperoleh kompensasi atas haknya. Berdasarkan hasil yang diperoleh dari indikator yang digunakan pada penelitian ini, variabel Kepuasan Kerja secara praktis dapat dianggap signifikan.

Selain itu diperoleh pula hasil dari nilai original sample dengan nilai sebesar 0.447 atau $44,7 \%$. Dari hasil pengolahan uji statistik uji-t pada thitung $2.810>$ ttabell 1.692 dan signifikansi ( $P$ Values) sebesar $0.005<0.05$. Berdasarkan hal tersebut sehingga bisa diambil keputusan bahwa Ho ditolak dan $\mathrm{Ha}$ diterima, diartikan variabel Kepuasan Kerja mempengaruhi Kinerja Guru secara signifikan. Perolehan ini sejalan dengan Baluyos et al., (2019) dimana diperoleh pengaruh atas Kepuasan Kerja pada Kinerja Guru. Selain itu Haryanto et al., (2020) ditemukan Kepuasan Kerja instrinsik mempengaruhi secara positif dan signifikan Kinerja Guru. Namun Pala'langan (2020) dan Hidayah \& Tobing (2018) menunjukkan Kepuasan Kerja tidak mempengaruhi Kinerja Guru.

\section{SIMPULAN DAN SARAN}

\section{Simpulan}

Berlandaskan hasil pengolahan uji data dengan menggunakan alat bantu SmartPLS 3.0 dan telah diperoleh hasil analisis serta pembahasan berkaitan dengan Pengaruh Penggunaan Teknologi Informasi, Motivasi Kerja, dan Kepuasan Kerja terhadap Kinerja Guru SMA Negeri 82 Jakarta. Kemudian berikut merupakan kesimpulan dari penelitian yaitu:

a. Diperoleh hasil pengujian variabel Penggunaan Teknologi Informasi (X1) yaitu terdapati pengaruh antara Penggunaan Teknologi Informasi terhadap Kinerja Guru SMA Negeri 82 Jakarta. Artinya, satu diantara faktor dari peningkatan kinerja guru dipengaruhi oleh penggunaan teknologi informasi yang digunakan guru. Guru yang mampu mengoperasikan IT dengan baik, akan memperoleh hasil kinerja yang optimal.

b. Diperoleh hasil dari variabel Motivasi Kerja didapati pengaruh terhadap Kinerja Guru. Dimana semakin besarnya motivasi yang diterima guru baik dari internal dan eksternal maka akan besar pula kinerja guru tersebut.

c. Diperoleh hasil dan membuktikan Kepuasan Kerja memiliki pengaruh terhadap Kinerja Guru. Artinya, besar diperolehnya kepuasan guru atas pekerjaanya memberikan semangat yang melahirkan kinerja yang maksimal.

\section{Saran}

Berlandaskan simpulan tertulis sebelumya, maka peneliti akan mengusulkan saran terkait hasil penelitian sebagai berikut:

a. Peneliti dapat memberikan saran kepada guru SMA Negeri 82 Jakarta berdasarkan hasil dari kesimpulan nilai loading factor terendah yakni pada indikator enchance effectiveness terkait permasalahan 
kelemahan penggunaan teknologi informasi sebagai media pembelajaran jarak jauh yang mana guru kesulitan dalam memahami karakteristik dan sikap peserta didiknya, hal ini bisa diatasi dengan guru menilai sejauh mana peserta didik tersebut aktif dan dapat disiplin seperti misalnya, aktif didalam kelas dalam berdiskusi, ketepatan join room, mengumpulkan tugas yang diberikan, ataupun kedisiplinan selama kegiatan room class berjalan. Bagi pimpinan sekolah, sebaiknya juga mampu memberikan arahan bagaimana caranya agar guru mampu memahami karakter siswa meskipun melalui pembelajaran jarak jauh serta mengamati kembali poin-poin yang perlu dipenuhi dalam mencangkup evaluasi atas attitude atau sikap siswa dengan menyesuaikan kondisi masa pandemi. Kemudian bagi penggunaan teknologi informasi dari loading factor tertinggi pada indikator increase productivity yang menunjukkan bahwa selama masa pendemi para guru lebih sering menggunakan teknologi informasi baik dalam mengikuti web-seminar/workshop pendidikan atau literasi lainnya, dengan hal ini maka setiap guru di SMA Negeri 82 Jakarta perlu mempertahankan dan terus melakukan peningkatan kemampuan guna memahami teknologi lebih lanjut sehingga mampu melaksanakan pembelajaran jarak jauh ini dengan lancar dan tetap menghasilkan kinerja yang terbaik.

b. Peneliti dapat memberikan saran kepada seluruh pihak internal SMA Negeri 82 Jakarta berdasarkan hasil dari kesimpulan pada dimensi instrinsik indikator keamanan. Dimana keamanan sekolah dalam menjaga informasi serta data-data penting masih cukup kurang aman, untuk itu diperlukan adanya evaluasi dan meningkatkan sisi keamanaan internal sekolah yang lebih baik dan terpercaya. Pihak terkait yang berada di sekolah sebaiknya melakukan evaluasi dan pengamatan terutama apabila datadata tersebut berada pada alat elektronik sekolah yang digunakan yakni dengan lebih memperhatikan usia alat elektronik yang dimiliki dan memperhatikan kelayakan pakainya. Selain itu bagi masing-masing guru dan kepegawaian tata usaha alangkah lebih baiknya jika menyimpan berkas atau file penting ketempat lain seperti flashdisk, memorycard, hard-disk dll serta tersedia dalam bentuk hard-copy cara ini dilakukan dengan maksud sebagai cadangan sekolah atas data-data penting agar tetap tersimpan dengan aman jika sewaktu-waktu terjadi hal tidak terduga. Kemudian bagi dimensi ekstrinsik indikator lingkungan kerja terutama pada lingkungan kerja fisik yang disediakan oleh sekolah dimana dengan adanya sarana dan prasarana yang menunjang mampu menghasilkan dorongan bagi para guru untuk memberikan hasil kerja yang lebih baik. Dengan begitu, maka bisa dijadikan contoh bagi organisasi lainnya bahwa penggunaan teknologi dalam pembelajaran mampu menunjang hasil kerja dan pencapaian tujuan organisasi tersebut sehingga sekolah yang telah memiliki fasilitas teknologi yang memadai bisa mulai menggunakannya dengan rutin atau tidak diabaikan. Bagi pihak internal SMA Negeri 82 Jakarta teknologi baik yang dimiliki secara pribadi maupun sebagai fasilitas yang diberikan sekolah kemudian bisa digunakan sebagai strategi untuk menghasilkan dan meningkatkan kinerja yang maksimal secara berkelanjutan dengan terus memperdalam pemahaman atas fungsinya.

c. Peneliti dapat memberikan saran kepada guru SMA Negeri 82 Jakarta berdasarkan hasil dari kesimpulan pada indikator penggajian yang menjelaskan bahwa terdapat sebagian guru yang masih merasa adanya keterlambatan atau penguluran waktu penerimaan gaji, hal ini dapat terjadi karena adanya perubahan sistem atau mekanisme dalam penggajian oleh pemerintah, terhambatnya akibat terbenturnya persyaratan penyaluran gaji, keterlambatan pernyampaian informasi, dan peng-inputan data yang masih kurang baik. Hal ini perlu menjadi perhatian utama bagi pemerintah untuk memberikan 
gaji sesuai dengan tanggal yang ditetapkan, memberikan pemberitahuan kepada guru jika terjadi keterlambatan, melakukan tindakan sesuai dengan mekanisme yang berlaku agar pemberian gaji guru tidak terlambat sehingga guru tetap dapat memenuhi kebutuhannya dan kepuasan guru dalam bekerja tidak terhambat, sebab kepuasan kerja yang yang terhambat mampu beresiko penurunan kinerja, oleh karena itu faktor-faktor penghambat kepuasan kerja perlu diatasi bahkan ditiadakan sehingga guru mampu menghasilkan kinerja yang optimal dan membantu peningkatan kualitas pendidikan di Indonesia. Kemudian pada indikator kesempatan untuk maju, dimana dalam hal ini dapat menjadi masukan dan pengamatan bagi pemerintah atau pimpinan sekolah untuk mempertimbangkan strategi jenjang karir yang memungkinkan bagi para guru meski dimasa sulit seperti saat ini, karena setiap guru menginginkan suatu peluang pengembangan potensi dirinya, oleh karena itu pimpinan dan pihak yang berwenang yang terkait dalam organisasi perlu memenuhi kebutuhan akan pengembangan potensi guru tersebut sebaik mungkin.

\section{R E F E R E N C E}

Adha, R. N., Qomariah, N., \& Hafidzi, A. H. (2019). Pengaruh Motivasi Kerja, Lingkungan Kerja, Budaya Kerja Terhadap Kinerja Karyawan Dinas Sosial Kabupaten Jember. Jurnal Penelitian IPTEKS, 4(1), 47-62. https://doi.org/10.32528/ipteks.v4i1.2109

Andriani, S., Kesumawati, N., \& Kristiawan, M. (2018). The Influence Of The Transformational Leadership And Work Motivation On Teachers Performance. International Journal of Scientific \& Technology Research, 7(7).

Baluyos, G. R., Rivera, H. L., \& Baluyos, E. L. (2019). Teachers' Job Satisfaction and Work Performance. Open Journal of Social Sciences, 07(08), 206-221. https://doi.org/10.4236/jss.2019.78015

Haryanto, A. T., Dewi, S. N., \& Fatonah, S. (2020). Kepuasan Kerja Intrinsik Memediasi Pengaruh Kompetensi Kerja dan Lingkungan Kerja Pada Kinerja di Sekolah Dasar. Jurnal Basicedu, 4(3), 754-764. https:/ /doi.org/10.31004/basicedu.v4i3.426

Hidayah, T., \& Tobing, D. S. K. (2018). The Influence Of Job Satisfaction, Motivation , And Organizational Commitment To Employee Performance. International Journal of Scientific \& Technology Research, $7(7)$.

Imam Ghozali. (2014). Structural Equation Modeling Metode Alternatif dengan Partial Least Squares (PLS) (IV). Universitas Diponegoro.

Kartini, D., \& Kristiawan, M. (2019). Pengaruh Tunjangan Profesi dan Motivasi Kerja Terhadap Kinerja Guru. Kelola: Jurnal Manajemen Pendidikan, 6(1), 25-33. https://doi.org/10.24246/j.jk.2019.v6.i1.p25-33

Makdori, Yopi. (2021). 60 Persen Guru di Indonesia Terbatas Kuasai Teknologi Informasi dan Komunikasi (online). from: www.merdeka.com. (14 Juli 2021).

Nugroho, W. S., H.S, E. W., \& Taufiq, M. (2019). KOMITMEN ORGANISASI MEMEDIASI PENGARUH TEKNOLOGI INFORMASI DAN KOMPETENSI TERHADAP KINERJA KARYAWAN (Studi Empiris Pada PT. Deksha Orla Tranggana Regional Jawa). Jurnal Ekonomi Manajemen Dan Akuntansi, 26(46), 68-81.

Nuskiya, A. F. (2018). The Effect of Information Technology on Employees ' Performance in the Banking Industry in Sri Lanka . Empirical Study Based on the Banks in Ampara District. European Journal of Business and Managemen, 10(16), 47-52. 
Pala'langan, A. Y. (2020). Pengaruh servant leadership, disiplin kerja, dan kepuasan kerja terhadap kinerja guru di sekolah xyz. Universitas Pelita Harapan.

Yunus, M. K., \& Bosowa, U. (2019). Pengaruh Teknologi Informasi dan Gaya Kepemimpinan terhadap Kinerja Organisasi pada PT. Bosowa Semen. ECONOMICS BOSOWA JOURNAL, 5(001), 14-32.

Zakaria, I. H., \& Leiwakabessy, T. F. F. (2020). Pengaruh Penggunaan Teknologi Informasi, Kemampuan Berkomunikasi Interpersonal, Dan Gaya Kepemimpinan Terhadap Kinerja Karyawan (Studi Empiris Pada Bank Syariah Di Kota Ambon). Jurnal Akuntansi : Transparansi Dan Akuntabilitas, 8(2), 117-126. https://doi.org/10.35508/jak.v8i2.2873 